\title{
STUDIES IN THE NUTRITION OF BIRDS.
}

\author{
By EGERTON CHARLES GREY, M.A., D.Sc., M.R.C.S.
}

(Late Professor of Chemistry in the Egyptian University, Cairo.)

(From the Chemical Department of the Egyptian University, Cairo, and the Biochemical Institute, Cambridge.)

(With 9 Text-figures.)

CONTENTS.

Section I.

ObServations on the nutrition of tame and wild Egyptian pigeons $\quad \mathbf{2 6 9}$

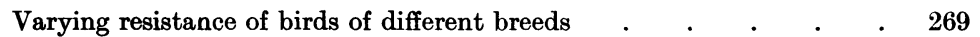

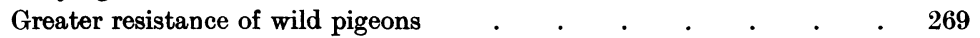

Comparison of rate of growth of tame and wild pigeons $\quad . \quad$. $\quad$. 270

Comparison of rate of loss of weight of tame and wild pigeons $\quad$ - $\quad 272$

Comparison of the weights of the organs of tame and wild pigeons $\quad$\begin{tabular}{l}
273 \\
\hline
\end{tabular}

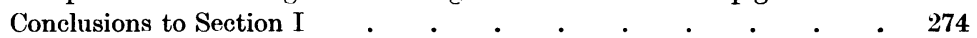

SeCtion II.

ObSERVATIONS ON THE RATE OF GROWTH, AND CHANGES IN THE ORGANS OF

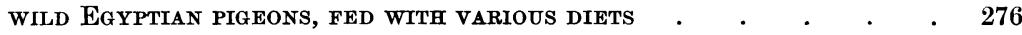

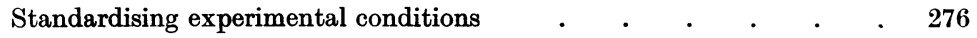

Inadequacy of a cereal diet especially for young pigeons _ . $\quad$. $\quad$ - 276

The value of various foods to the growing pigeon $\quad . \quad$. $\quad$. $\quad$. 278

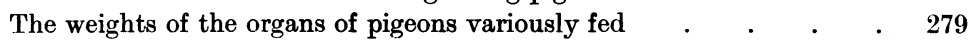

Discussion of results of the feeding experiments . $\quad . \quad+\quad . \quad+\quad 281$

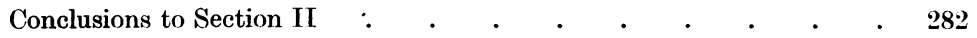

\section{SECTION III.}

A consideration of various factors which protect pigeons against THE HARMFUL EFFECTS OF AN EXCLUSIVELY CEREAL DIET, AND ESPECIALLY OF POLISHED RICE

Enumeration of the protective and harmful factors $\quad . \quad$. $\quad . \quad 283$

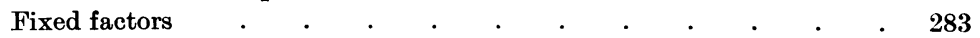

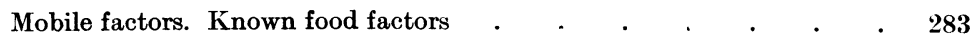

Nitrogenous substances known and unknown in possible relation to the

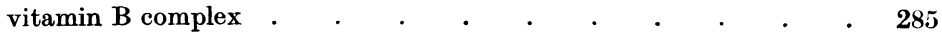

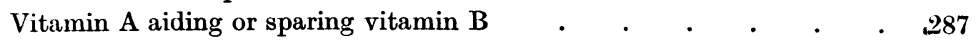

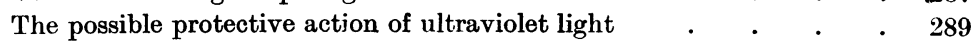

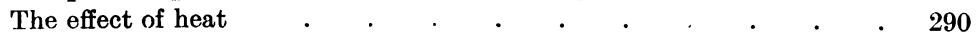

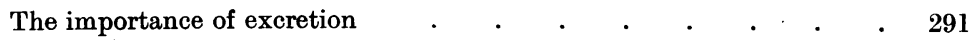

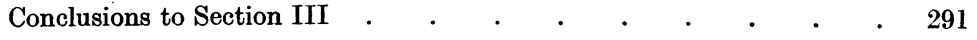

References to the literature cited in Sections I, II, ANd III $\quad$ • $\quad 293$ 


\section{Section I. Observations on the Nutrition of Tame and Wild Egyptian Pigeons.}

The Varying Resistance of Birds of Different Breeds.

ExPERIMENTs begun in 1925 in Egypt led the writer quickly to realise that comparable results in nutrition studies upon pigeons could only be obtained by a careful choice of the breed. It was found that lightly coloured birds and especially white birds were extremely sensitive to climatic change or to the harmful effects of an inadequate diet. On a diet of cereals only they thrived badly and were liable to intercurrent infections, and they never had the spirit of the darker birds unless fed much better, as for example on a diet of beans. On a diet of polished rice the lightly coloured birds did not show any of the convulsive symptoms, which are so characteristic of one type of the "rice disease" and which are responsible for the name avian "polyneuritis," applied to the condition. Probably the absence of such signs or symptoms is to be explained in that the birds in many cases died before the time required for the nervous system to become sufficiently involved for their manifestation, but this is not certain. Even however if the development of the nervous symptoms is a matter of time, the fact remains that the time requisite is so different in different birds that the clinical picture is in no way consistent unless birds of the same stock are selected for the experiments. McCarrison (1919) had similar experience with pigeons in India.

\section{Greater Resistance of Wild Pigeons.}

The observation that the darker, and in particular the completely black pigeons were in Egypt the most resistant type, led naturally to the choice of these for experimental work. But for the very reason that such birds are well adapted for the struggle for life, they are difficult to find in the towns, resisting retention in captivity. The lightly coloured birds are bred in the towns and readily retained, but the black birds must be sought in the villages where they are caught by the peasants shortly after they are born. At about two weeks they begin to fly, and the wings must be clipped to retain them in captivity.

These wild pigeons are incomparably more active than the town bred birds, but none the less they are quite readily usable for experimental work, and have the great advantage that they are not susceptible to cold, or other adverse conditions, being, as was anticipated, superior in this respect even to the black town bred birds. The wild pigeons moreover lend themselves to artificial feeding, owing to the wide pharynx. At two weeks although the bird appears very small and weighs perhaps only $150 \mathrm{grm}$., it is quite an easy matter to introduce a thumb into the pharynx, nor is the bird particularly sensitive to such treatment. The wild birds are naturally more difficult to catch, but when caught they do not show fright to the same extent as do, for example, white tame birds. It may be mentioned that to weigh the birds they are placed in a black cloth bag where they remain perfectly quiet. 
The writer chose these wild birds partly with a view to demonstrating the truth of an idea formed during the course of previous work upon birds of various colours, namely that black birds would show the typical convulsive symptoms which the light birds had failed to show, for it was felt that these symptoms were the expression of a well developed neuromuscular system. The theory turned out to be well founded. As was anticipated from the previous observations on the relation of colour to resistance in the town bred birds, the wild birds withstood the effects of an inadequate diet much better than the tame birds, and in about fifty per cent. of cases showed convulsive symptoms after about eighteen days' subsistence on polished rice, the symptoms being counteracted by the administration of yeast, and by other means shortly to be described. There seems therefore little doubt that the development of the typical nervous symptoms, "the convulsive form of avian polyneuritis," is related to the resistance of the bird and probably also to the degree of development of the neuromuscular mechanism.

The interest of comparing the tame and the wild birds is increased by the fact that amongst human beings the two types about to be described are by no means unfamiliar, and though perhaps less obvious in the west, where on the whole nutrition is good, the types are very distinct in the east, for example in Japan. McCarrison (1919, 1920, 1923 and 1924) describes such types in India and sees a connection between them and the type of Beriberi disease to which they are liable.

The first point of interest for comparison seemed to be the rate of growth in the two cases or, more strictly speaking, the rate of increase of weight, which for reasons to be mentioned later is by no means the same thing.

\section{Comparison of the Rate of Growth of Tame and Wild Pigeons.}

The rate of increase of weight, on a diet of beans (considered by the natives of Egypt as the ideal food for pigeons) is given for tame pigeons in Fig. 1, and for wild pigeons in Fig. 2.

It is clear from the two figures that the wild pigeons put on weight more slowly than the tame or town bred pigeons, for the fact must be emphasised that the amount of food, namely $25 \mathrm{grm}$. per day, was the same in both cases, and other precautions such as using the same sample of food, giving the same amount of water (water was given twice per day, morning and evening), and the general care of the birds was the same in the two cases.

On the other hand it must be pointed out that although the increase of weight was slower with the wild birds and the maximum reached was less, yet the wild birds were always stronger than the town bred birds of corresponding ages, and flew higher.

Having observed the difference in behaviour of the two types of bird in the matter of putting on weight, it seemed next of interest to see what would happen when the birds were made to lose weight. 


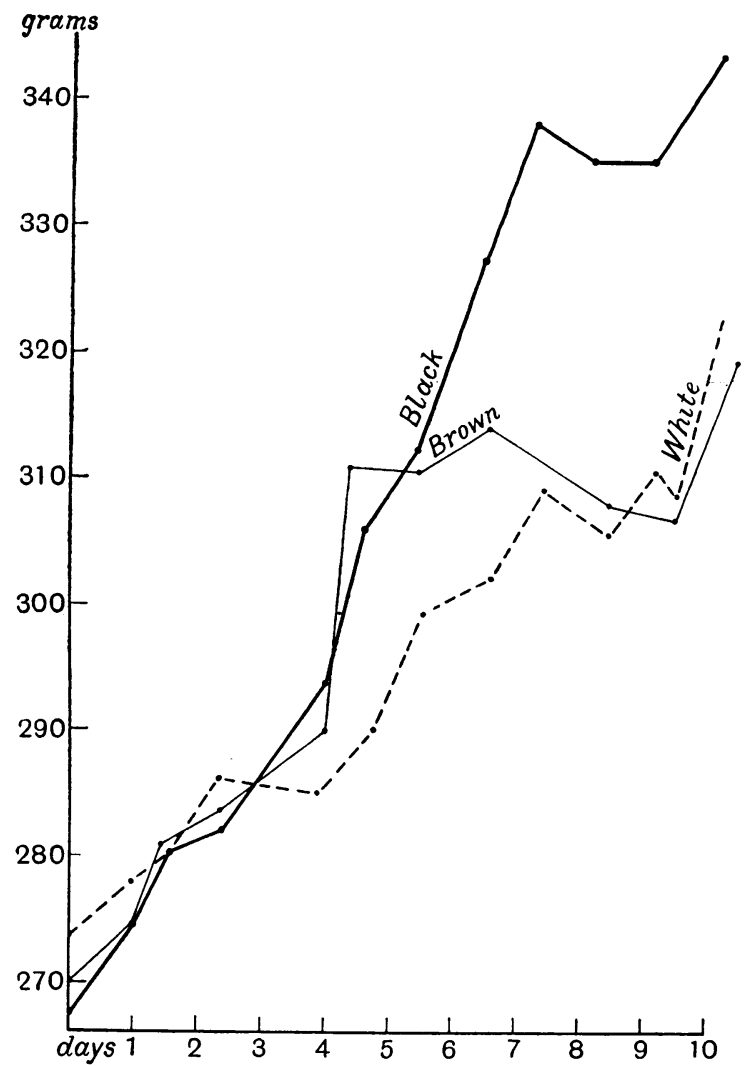

Fig. 1. Showing the rate of increase of weight of tame pigeons of various colours, when fed on a diet of beans. The pigeons were between two and three weeks old at the beginning of the experiment.

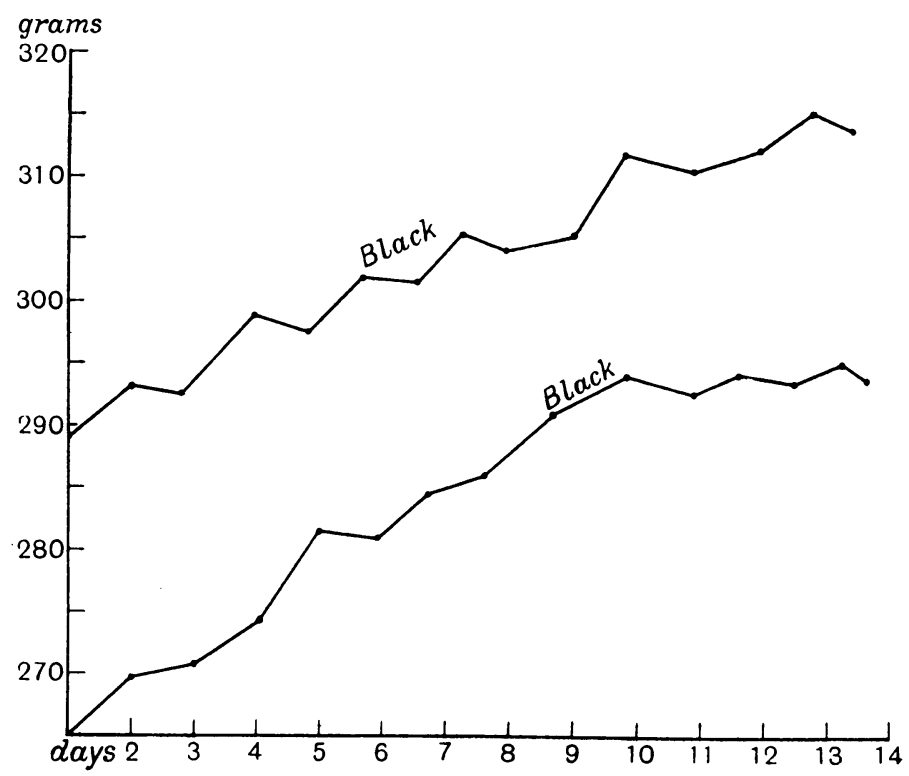

Fig. 2. Showing the much slower rate of increase of body weight, with wild pigeons, though fed in the same manner as the tame pigeons. 
As is well known birds fed on a diet of white rice rapidly lose weight, so that this method seemed suitable for the comparison.

\section{Comparison of the Rate of Loss of Weight of Tame and Wild Pigeons.}

Fig. 3 shows the rate of loss of weight with town bred pigeons, and Fig. 4 with wild pigeons, under the same conditions. The town bred lose at the rate of $8 \mathrm{grm}$. per day, the country bred or wild pigeons lose only half that amount. Consequently if the experiment is pushed to the degree of exhaustion the town birds die much earlier than the country birds.

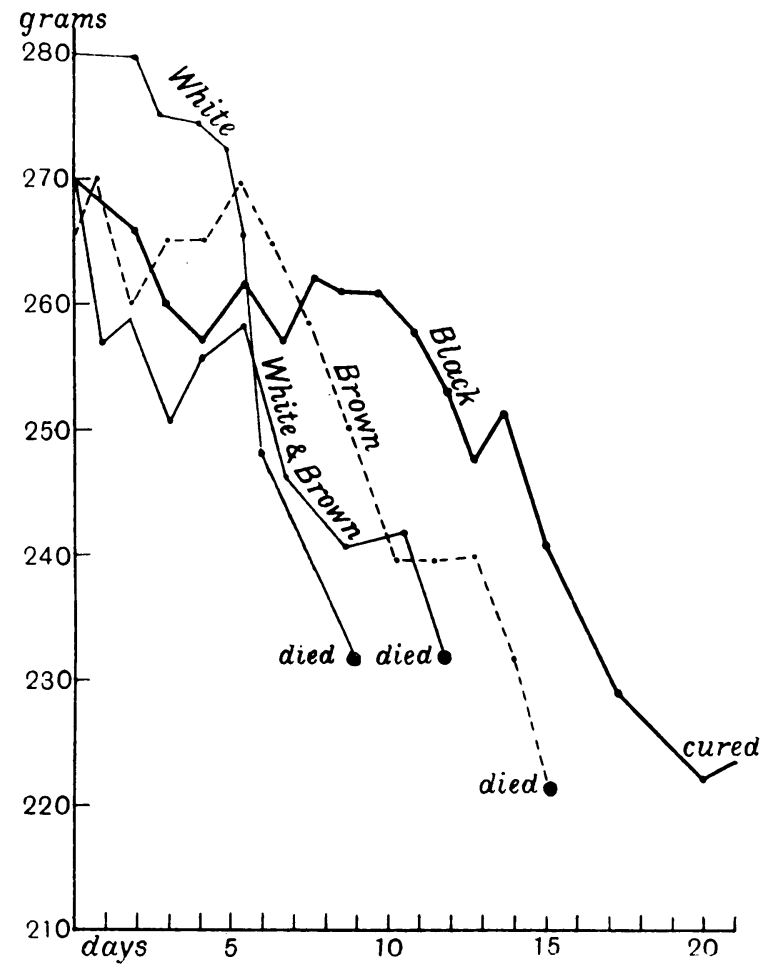

Fig. 3. Showing the rate of loss of weight of tame pigeons kept on a diet exclusively of polished rice.

It should be explained that in order to make the above comparison, i.e. to start with groups of birds in each case of the same weight it was necessary to feed the wild birds seven days longer than the town birds, namely twelve days in the former and nineteen days in the latter case, the food being $25 \mathrm{grm}$. of beans per day.

It appears therefore that the birds which put on weight rapidly also lose it rapidly, and this is surely evidence that increase of weight and growth are by no means the same thing. A considerable proportion of the increase of weight in the case of the town bred birds must be attributed to storage, an increase not of true tissue bioplasm, but of paraplasm. 
It seems but reasonable to picture that if this storage takes place throughout the body, its formation and especially its subsequent resolution or autolysis, must interfere with the efficient action of the tissues, and it might explain why the musculature of the one type is so much less active than the other.

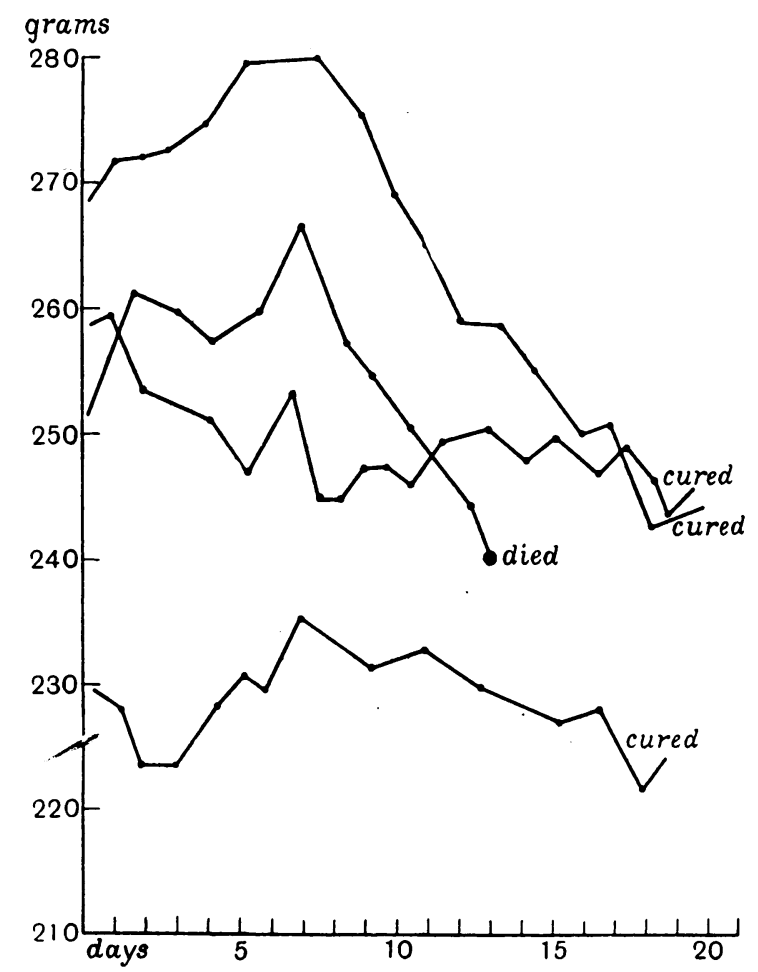

Fig. 4. Showing the much slower loss of weight of wild pigeons under the same conditions as described for Fig. 3.

\section{Comparison of the Weights of the Organs of Tame and Wild Pigeons.}

That, however, the storage must be throughout the body and therefore in the muscles themselves also is shown from the weights of the various organs, for although the viscera weigh more in the case of the tame pigeons, the difference from the viscera of the wild pigeons does not amount to more than a small fraction of the difference in increase of body weight. The facts are seen from Table I, which gives the weights of the various organs of the two types of birds.

Table I shows that the viscera of the town bred birds weigh more than the viscera of wild birds of the same total body weight, yet this increase is not in respect of all the viscera but of two especially, namely the intestines and the liver, these being about fifty per cent. greater in the case of the town bred bird. Yet it is clear that this does not indicate that the wild birds eat less or are adapted to eat less because the gizzard is the same weight in the two cases, as 
is also the pancreas. The heart of the wild bird seems a little bigger but the differences are not sufficient to make an absolute statement on this point.

The total weight of the viscera amounts to about one-sixth of the total body weight so that it is evident that a very large proportion of the weight gained is represented by increase of weight in the skeletal system. If this increase is protoplasm it is to the good, but if paraplasm its value is uncertain. The fact that with the wild bird it is lost slowly and with the town bird quickly when both are kept on a white rice diet, seems clear evidence that with the

Table I. The Weights of Organs of Tame and Wild Pigeons.

Tame Pigeons.

\begin{tabular}{|c|c|c|c|c|c|c|c|c|c|c|}
\hline No. & $\begin{array}{l}\text { Total } \\
\text { body } \\
\text { weight }\end{array}$ & Heart & Lungs & Liver & Gizzard & Intestines & Spleen & Pancreas & Kidneys & Brain \\
\hline 1 & 283 & $3 \cdot 4$ & $4 \cdot 4$ & $7 \cdot 9$ & $8 \cdot 6$ & $8 \cdot 1$ & $0 \cdot 7$ & 1.5 & 3.5 & $1 \cdot 6$ \\
\hline 2 & 281 & $3 \cdot 2$ & $4 \cdot 4$ & $8 \cdot 8$ & $7 \cdot 6$ & $8 \cdot 3$ & $0 \cdot 3$ & $1 \cdot 7$ & - & - \\
\hline 3 & 307 & $3 \cdot 7$ & $4 \cdot 8$ & $8 \cdot 5$ & $7 \cdot 2$ & $6 \cdot 0$ & $0 \cdot 7$ & $1 \cdot 7$ & $3 \cdot 9$ & $2 \cdot 1$ \\
\hline 7 & 284 & $2 \cdot 8$ & $4 \cdot 2$ & $7 \cdot 9$ & $8 \cdot 0$ & $10 \cdot 0$ & 0.7 & 1.8 & - & - \\
\hline 8 & 230 & $2 \cdot 8$ & $4 \cdot 4$ & $8 \cdot 9$ & $7 \cdot 2$ & $8 \cdot 0$ & 0.5 & 1.5 & - & - \\
\hline 13 & 302 & $3 \cdot 6$ & $5 \cdot 5$ & $10 \cdot 8$ & $8 \cdot 2$ & $6 \cdot 8$ & 1.0 & 1.8 & 3.5 & - \\
\hline
\end{tabular}

\section{Wild Pigeons.}

\begin{tabular}{|c|c|c|c|c|c|c|c|c|c|}
\hline 283 & $5 \cdot 3$ & $4 \cdot 9$ & $6 \cdot 3$ & $9 \cdot 4$ & $5 \cdot 6$ & 0.3 & 1.4 & $3 \cdot 3$ & $2 \cdot 1$ \\
\hline 286 & $3 \cdot 1$ & $4 \cdot 2$ & $6 \cdot 1$ & $8 \cdot 7$ & $6 \cdot 1$ & 0.4 & 1.9 & $3 \cdot 7$ & 1.8 \\
\hline 299 & $3 \cdot 6$ & $4 \cdot 6$ & $6 \cdot 3$ & $8 \cdot 4$ & $5 \cdot 3$ & 0.4 & $1 \cdot 3$ & $3 \cdot 4$ & 1.8 \\
\hline 260 & $3 \cdot 2$ & $4 \cdot 1$ & $5: 6$ & $7 \cdot 9$ & $6 \cdot 1$ & $0 \cdot 4$ & $1 \cdot 4$ & $3 \cdot 7$ & $1 \cdot 6$ \\
\hline
\end{tabular}

All pigeons were fed up to approximately the same weight, on a diet of beans.

former the gained weight is largely valuable protoplasm which it is desirable to retain, whereas with the latter it is superfluous paraplasm which it is desirable to remove. There is observable too in the case of the weight curve of the wild pigeon, a step like descent, indicating temporary adaptations to lower levels of physiological activity, or some sort of resistance to loss of substance, whereas no such steps are observed with the town bred birds, owing possibly to the extensive hydrolysis of paraplasm masking the autolysis of the protoplasm.

With such remarkable differences in the behaviour of animals of the same species kept under the same conditions in the laboratory, it is not surprising that very contradictory results are reached, unless the animals are specially selected for the purpose of experiment. It was found too that the age of the pigeons, as well as the season of the year made a difference in the effects observed.

\section{Conclusions to Section I.}

The fact that the observations upon the differences between town bred and wild pigeons are so much in keeping with common observation with regard to man, and clinical experience, makes it reasonable to consider that the two types here described are general types in the animal kingdom, namely the "active" which we may also call the "neuromuscular" type, and the passive or "digestive" type. In the former the skeletal system is better developed 
than in the latter, the food absorbed is more completely utilised in producing energy, and there is very much less storage of material either in the viscera or in the tissues generally of the skeletal system. Body weight increases more slowly than with the "digestive" type, but the material built into the body is more firmly held in time of food shortage, from which we may infer that the material responsible for the increase of weight is more truly part of the animal itself, in other words bioplasm, as opposed to a storage of intra- or extra-cellular paraplasm, which appears to be the explanation of the rapid increase of weight on a rich diet, and equally rapid loss of weight on a poor diet, so characteristic of the passive or "digestive" type of animal.

The recognition of these two types should be of value to experimenters, and enable them to obtain more consistent results in work on animal nutrition. According to the view here described, it will be animals of recent origin from wild stock, and inheriting the dominant characters useful for the struggle for life, which will show best the neuritic symptoms characteristic of deficiency disease; for with the digestive type of animal the resistance is so low, and possibly the excessive digestion or autolysis which goes on in the tissues of such animals during the rapid loss of weight aggravates the condition by intoxication with autolytic products, that death ensues through exhaustion of the heart or other tissues before the nervous system has had time to become involved.

There are as a matter of fact, in Japan, two very characteristic types of response to malnutrition, one of which is the neuritic type of avitaminosis, well recognised as Beriberi, the other, much more common, especially in the towns, is characterised by symptoms of exhaustion and general muscular weakness. A recognition of a marked difference in response of the two types of individual, namely the passive and the active, to the same conditions of malnutrition may help to clear up what has been an apparent contradiction, and it is possible that just as with the typical polyneuritis much good has come of studies on birds, so by extending the studies to the two types of birds or other animals further light will be thrown on the types of malnutrition observed in man.

Naturally these types will overlap, but knowing the history and the habits of the individual we should be in a position to predict to a certain degree what the course of the symptoms will be. For example, with active men leading an open air life and especially with a race whose nutrition had been habitually good, we should expect under conditions of inadequate nourishment a considerable resistance, and ultimately the symptoms of neuritis and a tendency towards the dry type of Beriberi the resistance making possible the gradual development of a chronic condition. On the other hand, with the passive type of individual with poor muscular development we should anticipate a rapid exhaustion, alimentary disturbances, and the dropsical condition associated with the wet type of Beriberi and with many of the conditions classified by Japanese writers as possibly Beriberi but certainly deficiency disease. 


\section{Section II. Observations on the Rate of Growth, and Changes in the Organs of Wild Egyptian Pigeons, fed with Various Diets.}

\section{Standardising Experimental Conditions.}

Having found, as explained in Section I of this series, that of Egyptian pigeons the black were the most suitable for nutrition experiments, and that most consistent results could be obtained by the employment of wild pigeons, owing to the superior resistance of these birds and for other reasons previously mentioned, it became next of importance, in order to standardise conditions, to understand the effects of normal diets, and in particular to know what kind of food is most suitable for the birds at different times in their lives. Such information was required in order to be able to keep the birds in good condition prior to experiments, for owing to the very different behaviour of birds of different ages, it became necessary before commencing an experiment to sort them out into groups of approximately the same degree of development, and it was an advantage for this purpose to have some standard system of preparation. Doubtless the ideal method would be to breed the birds oneself, for when birds are purchased in the market they have often been reared on very different food, which must affect their subsequent behaviour when placed on any particular diet.

Without however going so far as to breed the pigeons, a close approach was made to this ideal by encouraging the native peasants to bring in pigeons as young as possible, and these were then kept on a nutritious diet, and under as far as possible natural conditions, until ready for experiments. The birds were never placed in cages in the day-time, but in a very large room, where they had plenty of liberty. In the hottest months tanks were provided in which the birds could bathe. The pigeons could thus be kept under almost ideal conditions until of sufficient weight to be suitable for an experiment. Frequently the pigeons when brought in weighed less than $150 \mathrm{grm}$. and they were kept on a diet, generally of beans, until they weighed about 200 or $250 \mathrm{grm}$. In this way it was possible to start with a number of birds in much the same condition as regards previous history, there being also plenty of time for the selection of the groups.

\section{Inadequacy of a Cereal Diet especially for Young Pigeons.}

The young wild pigeon, and the same remark applies to the young tame pigeon, thrives very badly on a diet of cereals only, but it thrives excellently on a diet of beans. This is the common Egyptian bean, which forms perhaps the most important staple food of the peasants themselves. As will be seen from Fig. 5, the young pigeons cannot grow on a diet of maize or natural rice only, if they are put on to this restricted diet at the beginning of the second fortnight of life or earlier, though later, namely in the third fortnight of life, they are able to grow slowly on a cereal diet, as may be seen from Fig. 6 . The significance of 
such results is unmistakable, and it is clear that the statement made by certain writers that whole rice is a perfect food for birds, requires modification in the light of these facts. And indeed the results appear even more significant in connection with the problem of the nutrition of rice-eating people, a matter which will be referred to later, and has already been pointed out elsewhere ${ }^{1}$. Reference may be made here to the work of Plimmer and his colleagues (1927)

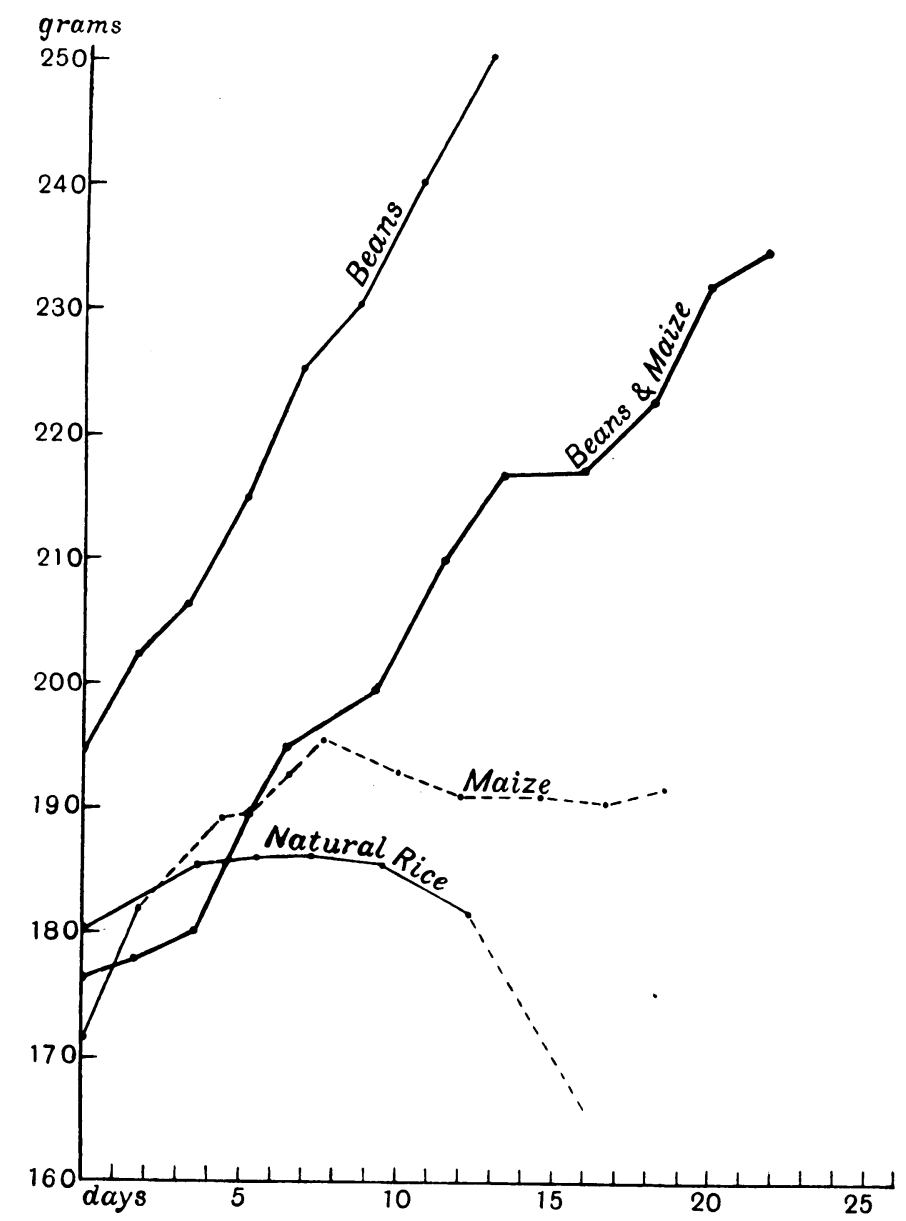

Fig. 5. Showing the rate of increase of body weight in wild pigeons, in the second fortnight of life, when variously fed.

who have obtained somewhat analogous results with chickens, although attributing the results to lack of vitamin B.

Experiments were made upon the effect of adding cod liver oil to the diet of the birds, but although the birds take the oil quite well it appears to interfere with their digestion, at any rate no increased growth was observed in the few experiments tried on the effect of adding the oil to a cereal diet. Never-

1 Report to the League of Nations on the Food of Japan. (In print.) 
theless a remarkable effect was observed in the subsequent reaction of the birds to a diet of polished rice, when they had been given early in the experiments small doses of the oil, the treatment apparently protecting them to some extent from the harmful effects of the rice diet. This point however will be dealt with in Section III of this communication.

\section{The value of Various Foods to the Growing Pigeon.}

The growth curves in Fig. 6 represent averages of four or five experiments on each kind of food. It would appear from the results that it is best to begin giving the birds beans only and gradually diminish the proportion of beans by

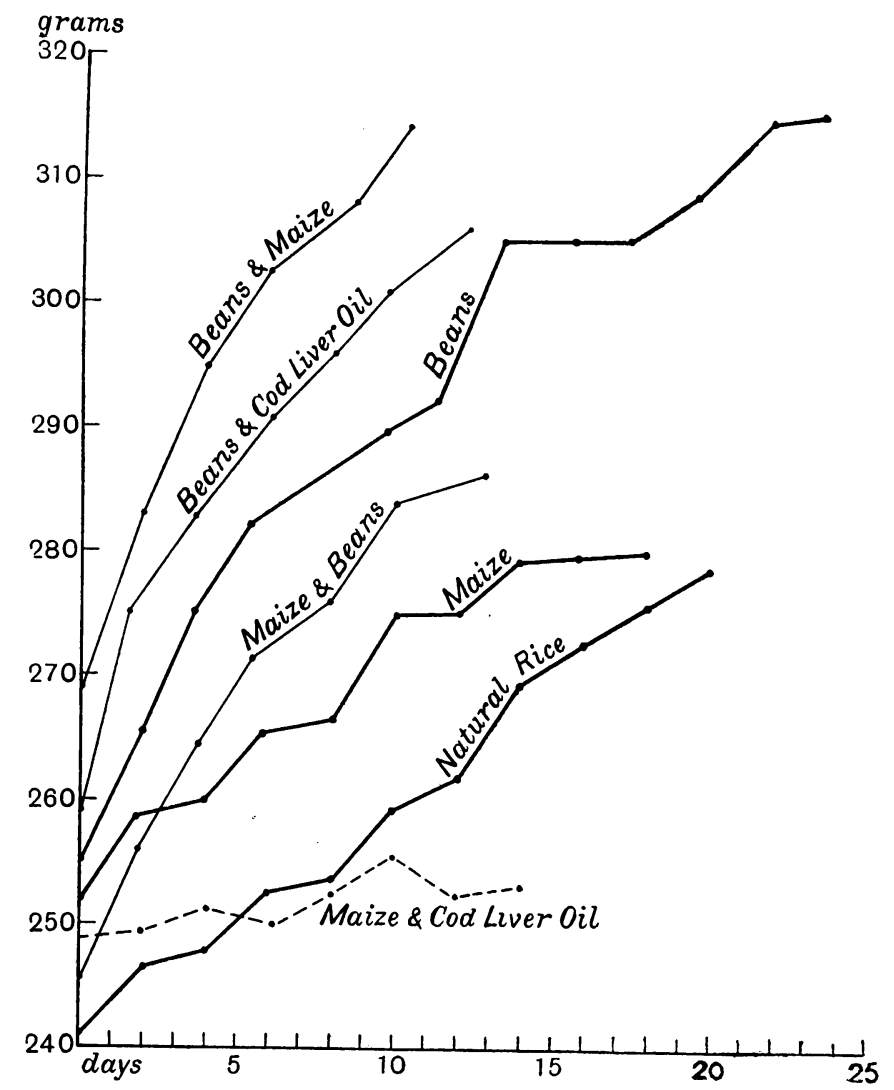

Fig. 6. Showing the rate of increase of body weight in wild pigeons in the third fortnight of life, when variously fed.

addition of cereals as the birds get older. In all the experiments represented in Fig. 6, the total amount of food given was $25 \mathrm{grm}$. per day. The expression 'beans and maize' in Fig. 6 means 20 of beans to 5 of maize, and conversely with the expression 'maize and beans.'

As a general routine measure in feeding the birds, therefore, it was found convenient to begin with $25 \mathrm{grm}$. of beans per day with pigeons weighing under 
$200 \mathrm{grm}$., and to replace $5 \mathrm{grm}$. of the beans by cereals for each increment of $50 \mathrm{grm}$. in the weight of the bird. The beans should be given dry, for it is not only no advantage, but a very distinct disadvantage to soak the beans before giving them. Soaked beans presumably do not so well absorb the acid juices of the crop, and it is found that they remain a longer time in the crop before being passed on to be ground up in the gizzard. Neither could any beneficial results be obtained by substituting germinated beans for the ungerminated, and in any case the food so treated is too bulky and the bird would need to be fed several times in the day.

Exposure of the food to ultraviolet light for ten minutes gave some interesting results in the case of rice, which will be referred to in Section III of this communication, but in the case of beans there was no advantage, and with thirty minutes' exposure a distinct disadvantage, as measured by the subsequent rate of growth of the birds.

\section{The Weights of the Organs of Pigeons variously fed.}

Having thus by the choice of the breed of bird, and by a preliminary period of feeding, assured more constant conditions for experimental work, the next point of interest seemed to be to study the changes which occurred in the organs of the pigeons, when fed on different diets, with a view to being able subsequently to interpret any changes which might be observed in malnutrition. How different the weights of the organs are with different breeds of pigeons has been pointed out in Section I of this series, in which the tame and wild Egyptian pigeon were to some extent contrasted, both having been fed under the same conditions until they reached the same weight. The next fact therefore to be determined was as to the variations in the organs of the one breed of pigeons, under varying conditions of diet. Accordingly black wild Egyptian pigeons were employed for these experiments, and after three or four weeks' feeding on various diets, were killed, and the weight of the organs ascertained. In the case of gizzard, intestine and heart, the organs were opened up and contents washed out in a gentle stream of water, after which they were allowed to drain on filter paper before being weighed. The organs were then cut up and dried on the water bath and subsequently in the oven at $110^{\circ} \mathrm{C}$., and the weight of dry matter determined, this precaution being important in view of the possible variations in the water content of organs leading to a wrong conclusion as to change in weight of solid substance.

Table II sets out the weights of the organs as they were found with the wild pigeons after feeding on various diets.

Table III gives the weights of dry matter obtained from the organs after drying in the manner above described.

The following facts appear from these experiments.

Compared to the organs of a bean-fed bird the organs of the cereal-fed bird are smaller, and mostly softer and contain more water. The changes are greatly accentuated on a diet of polished rice. But in very young birds they may be 
Table II. Weights of Organs of Wild Egyptian Pigeons, fed on Various Diets. Body weight

\begin{tabular}{|c|c|c|c|c|c|c|c|c|c|c|c|c|}
\hline \multicolumn{4}{|c|}{$\mathrm{N}^{-J}$} & \multirow{3}{*}{ Heart } & \multirow{3}{*}{\multicolumn{2}{|c|}{$\begin{array}{l}\text { Lungs Liver } \\
\text { Fed on beans. }\end{array}$}} & \multirow{3}{*}{$\begin{array}{l}\text { Giz- } \\
\text { zard }\end{array}$} & \multirow{2}{*}{\multicolumn{2}{|c|}{$\begin{array}{l}\text { In- } \\
\text { testines Spleen }\end{array}$}} & \multirow{3}{*}{$\begin{array}{l}\text { Pan- } \\
\text { creas }\end{array}$} & \multirow{3}{*}{ Kidney } & \multirow{3}{*}{ Brain } \\
\hline No. & Initial & Final & Gain & & & & & & & & & \\
\hline & & & & & & & & & & & & \\
\hline 14 & 255 & 344 & 89 & $3 \cdot 9$ & $5 \cdot 3$ & 6.4 & $8 \cdot 8$ & $5 \cdot 8$ & 0.8 & $1 \cdot 5$ & $3 \cdot 4$ & $1 \cdot 9$ \\
\hline 66 & 258 & 299 & 41 & $3 \cdot 6$ & $4 \cdot 6$ & $6 \cdot 3$ & $8 \cdot 4$ & $5 \cdot 3$ & 0.4 & $1 \cdot 3$ & $3 \cdot 4$ & $1 \cdot 8$ \\
\hline 67 & 193 & 286 & 93 & $3 \cdot 1$ & $4 \cdot 2$ & $6 \cdot 1$ & $8 \cdot 7$ & $6 \cdot 1$ & 0.4 & 1.9 & $3 \cdot 7$ & $1 \cdot 8$ \\
\hline 69 & 253 & 283 & 30 & $\mathbf{3} \cdot \mathbf{3}$ & $4 \cdot 9$ & $6 \cdot 3$ & $9 \cdot 4$ & $5 \cdot 6$ & $0 \cdot 3$ & $1 \cdot 4$ & $3 \cdot 3$ & $2 \cdot 0$ \\
\hline 70 & 193 & 265 & 72 & $3 \cdot 0$ & $4 \cdot 1$ & $9 \cdot 5$ & $7 \cdot 4$ & $4 \cdot 9$ & 0.4 & $1 \cdot 4$ & $3 \cdot 7$ & $1 \cdot 6$ \\
\hline & & & & & Fed or & maize & & & & & & \\
\hline 6 & 270 & 315 & 45 & $3 \cdot 6$ & $4 \cdot 2$ & $9 \cdot 3$ & $7 \cdot 9$ & $6 \cdot 4$ & 0.4 & $1 \cdot 5$ & $3 \cdot 2$ & $1 \cdot 8$ \\
\hline 10 & 262 & 283 & 21 & $3 \cdot 2$ & $4 \cdot 6$ & $10 \cdot 0$ & $6 \cdot 9$ & $5 \cdot 6$ & 0.4 & $0 \cdot 7$ & $2 \cdot 6$ & $1 \cdot 7$ \\
\hline 16 & 220 & 232 & 12 & $3 \cdot 4$ & $4 \cdot 5$ & $9 \cdot 3$ & $7 \cdot 7$ & $6 \cdot 3$ & 0.5 & $1 \cdot 4$ & $1 \cdot 3$ & 一 \\
\hline 18 & 236 & 252 & 16 & $3 \cdot 0$ & $5 \cdot 5$ & $10 \cdot 0$ & $7 \cdot 3$ & $6 \cdot 1$ & 0.4 & $1 \cdot 5$ & $2 \cdot 3$ & \\
\hline 71 & 221 & 260 & 39 & $3 \cdot 2$ & $4 \cdot 1$ & - & $7 \cdot 9$ & $6 \cdot 0$ & 0.5 & $1 \cdot 1$ & $2 \cdot 3$ & \\
\hline 81 & 228 & 244 & 16 & $3 \cdot 2$ & $3 \cdot 6$ & $9 \cdot 8$ & $7 \cdot 4$ & $5 \cdot 0$ & 0.5 & $1 \cdot 4$ & $3 \cdot 8$ & \\
\hline
\end{tabular}

Fed on white rice and $1 \mathrm{grm}$. yeast daily.

\begin{tabular}{|c|c|c|c|c|c|c|c|c|c|c|c|}
\hline 28 & 266 & 276 & 10 & $3 \cdot 6$ & $5 \cdot 0$ & $8 \cdot 3$ & $7 \cdot 8$ & $3 \cdot 8$ & 0.4 & $1 \cdot 3$ & $\mathbf{3} \cdot \mathbf{3}$ \\
\hline 31 & 250 & 270 & 20 & $3 \cdot 7$ & $3 \cdot 8$ & $7 \cdot 6$ & $6 \cdot 1$ & 3.9 & 0.4 & $1 \cdot 3$ & $2 \cdot 7$ \\
\hline 86 & 201 & 260 & 59 & $2 \cdot 6$ & $4 \cdot 4$ & $11 \cdot 0$ & $5 \cdot 7$ & $6 \cdot 0$ & $0 \cdot 6$ & $1 \cdot 3$ & $3 \cdot 1$ \\
\hline 90 & 235 & 258 & ?2 & 25 & 25 & 0.7 & 5.9 & 5.4 & 0.4 & 1.2 & 2.9 \\
\hline
\end{tabular}

Fed on white rice and $0.5 \mathrm{grm}$. yeast daily.

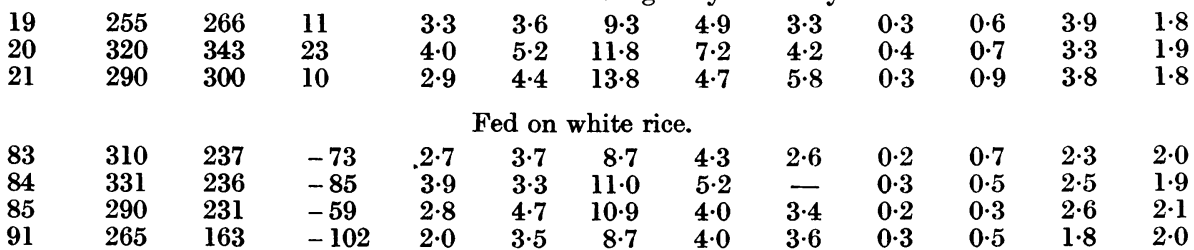

Table III. Weights of Dried Organs of Wild Egyptian Pigeons variously fed.

\begin{tabular}{|c|c|c|c|c|c|c|c|c|c|c|}
\hline No. & Food & Heart & Lungs & Liver & $\begin{array}{l}\text { Giz- } \\
\text { zard }\end{array}$ & $\begin{array}{c}\text { In- } \\
\text { testines }\end{array}$ & Kidney & Spleen & $\begin{array}{l}\text { Pan- } \\
\text { creas }\end{array}$ & Brain \\
\hline $\begin{array}{r}3 \\
14\end{array}$ & $\left\{\begin{array}{c}\text { Beans } \\
,\end{array}\right.$ & $\begin{array}{l}0.91 \\
0.92\end{array}$ & $\begin{array}{l}0.57 \\
0.92\end{array}$ & $\begin{array}{l}2 \cdot 01 \\
1 \cdot 86\end{array}$ & $\begin{array}{l}2 \cdot 18 \\
2 \cdot 85\end{array}$ & $\begin{array}{l}1 \cdot 26 \\
1 \cdot 76\end{array}$ & $\begin{array}{l}1.05 \\
0 \cdot 44\end{array}$ & $\begin{array}{l}0 \cdot 15 \\
0 \cdot 19\end{array}$ & $\begin{array}{l}0 \cdot 47 \\
0 \cdot 35\end{array}$ & $\begin{array}{l}0 \cdot 34 \\
0 \cdot 44\end{array}$ \\
\hline $\begin{array}{r}6 \\
10 \\
17 \\
73\end{array}$ & $\begin{array}{c}\text { Maize } \\
\text {," } \\
\text {," }\end{array}$ & $\begin{array}{l}0.98 \\
0.82 \\
0.53 \\
0.52\end{array}$ & $\begin{array}{l}0.48 \\
0.90 \\
0.48 \\
0.45\end{array}$ & $\begin{array}{l}2 \cdot 54 \\
2 \cdot 60 \\
1 \cdot 81 \\
3 \cdot 07\end{array}$ & $\begin{array}{l}2 \cdot 32 \\
2 \cdot 37 \\
2 \cdot 56 \\
1 \cdot 52\end{array}$ & $\begin{array}{l}2 \cdot 30 \\
1 \cdot 86 \\
1 \cdot 10 \\
0 \cdot 75\end{array}$ & $\begin{array}{l}0 \cdot 65 \\
0 \cdot 54 \\
0 \cdot 28 \\
0 \cdot 35\end{array}$ & $\begin{array}{l}0 \cdot 10 \\
0 \cdot 10 \\
0 \cdot 14 \\
0 \cdot 01\end{array}$ & $\begin{array}{l}0.40 \\
0.23 \\
0.21 \\
0.08\end{array}$ & $\begin{array}{l}0 \cdot 32 \\
0 \cdot 41 \\
0 \cdot 35 \\
0 \cdot 35\end{array}$ \\
\hline $\begin{array}{l}28 \\
31\end{array}$ & $\begin{array}{l}\text { Rice }+1 \text { grm. } \\
\text { yeast }\end{array}$ & $\begin{array}{l}0 \cdot 81 \\
0.96\end{array}$ & $\begin{array}{l}0 \cdot 65 \\
0.57\end{array}$ & $\begin{array}{l}1.06 \\
1.95\end{array}$ & $\begin{array}{l}2 \cdot 25 \\
1 \cdot 70\end{array}$ & $\begin{array}{l}1 \cdot 13 \\
1 \cdot 87\end{array}$ & $\begin{array}{l}0 \cdot 40 \\
0 \cdot 37\end{array}$ & $\frac{0 \cdot 10}{-}$ & $\begin{array}{l}0 \cdot 23 \\
0 \cdot 23\end{array}$ & $\begin{array}{l}0 \cdot 31 \\
0 \cdot 36\end{array}$ \\
\hline $\begin{array}{l}19 \\
20\end{array}$ & $\begin{array}{c}\text { Rice }+0.5 \mathrm{grm} \\
\text { yeast }\end{array}$ & $\begin{array}{l}0 \cdot 78 \\
0 \cdot 88\end{array}$ & $\begin{array}{l}0.47 \\
0.70\end{array}$ & $\begin{array}{l}2 \cdot 21 \\
3 \cdot 38\end{array}$ & $\begin{array}{l}1 \cdot 60 \\
2 \cdot 00\end{array}$ & $\begin{array}{l}0 \cdot 84 \\
1 \cdot 44\end{array}$ & $\begin{array}{l}0 \cdot 46 \\
0 \cdot 39\end{array}$ & $\begin{array}{l}0.04 \\
0.08\end{array}$ & $\begin{array}{l}0 \cdot 12 \\
0 \cdot 18\end{array}$ & $\begin{array}{l}0 \cdot 31 \\
0 \cdot 35\end{array}$ \\
\hline
\end{tabular}

For initial and final weight of pigeon see Table II, under each number.

The organs were dried to constant weight at $110^{\circ} \mathrm{C}$.

seen with whole rice. In any case the difference is rather of kind than of quality.

The chief changes in the organs are as follows:

The liver increases in weight and in solid matter, though it may be greatly softened and is obviously abnormal. In very acute cases it may be disintegrated, but in milder cases there is always increase.

The heart, lungs and brain do not alter to the same extent as the other organs, when the diet is of cereals, and even on polished rice the heart greatly 
resists dissolution while any loss of weight in the brain is not observed except in very protracted cases of deficiency.

All other tissues lose weight and especially the muscles and glandular tissues.

Most remarkable for its dissolution is the pancreas.

\section{Discussion of Results of the Feeding Experiments.}

The observations recorded in this communication confirm the findings of McCarrison (1919) in India, namely that the effect of an inadequate diet, such as polished rice, induces changes in all the organs of the body, which however resist such changes in varying degrees. The clinical picture given by the animal when inadequately fed will therefore vary with the resistance of its organs to change. If the events are hurried, the nervous system which is resistant to change will not become involved, the picture being one of exhaustion, dystrophy, oedema, ending in death by heart failure; pulmonary congestion, hæmorrhage into the lungs, and fluid in the pericardium, being frequent concomitant changes. In Egypt this hurried picture of deficiency disease was found to be given particularly by tame birds, the more resistant wild pigeons living longer under such conditions, and quite generally until the central nervous system had become involved, as evidenced by what are called the neuritic symptoms, evidence of cerebellar affection being often very marked. Such symptoms never appeared in these experiments until after three weeks of the feeding on polished rice.

It is true that the birds go lame early in the course of the disease, but as the symptoms can be rapidly cured, there cannot at this stage be any profound change in the nerves themselves.

The experiments show that what is brought on in an acute form by a diet of polished rice, is also brought on slowly or in a less acute form by such cereals as maize and whole rice, which are presumed to contain sufficient vitamin B complex (Berg 1927, Stepp 1927). There are therefore many factors to be taken into consideration as regards the food causing what the Japanese people often call "rice disease," and as Drummond (1927) points out no theory is as yet satisfactory, though for reasons which will be described in Section III of this communication the writer cannot agree that starvation and the rice disease are one and the same.

It is clear also, as McCarrison $(1919,1924)$ concludes, that besides those factors, including vitamins, which we may call labile factors, concerned in protecting the animal against a one-sided diet, there are other factors in the tissues of the animal which we may call fixed factors. McCarrison found pigeons from various districts in India varied in susceptibility to the rice disease, and human beings from different districts and of different castes varied in response also. Such findings are so much in parallel with the observations the writer has made in Egypt on the difference between birds of different colours, and particularly 
on the great difference between the tame and the wild birds as regards their resistance to a poor diet and other adverse conditions, that it seems almost certain that a very close. study of the pathology of the disease in birds will throw light not only on the type of Beriberi which is characterised by degenerative lesions in the peripheral nerves, but also on the condition which in Japan at least is by far the most general; namely the condition of general exhaustion, early cardiac trouble and gastritis, which is so analogous to that aspect of the rice disease in birds, which up to the present has been neglected in the desire to study only the neuritic symptoms.

It does not seem to the writer helpful to adopt McCarrison's $(1919,1924)$ idea of a specific virus existing in the birds in connection with the development of the disease. It seems less committal to picture fixed factors in the tissues differing as in the case of wild and tame birds, either in kind or quality. Upon these fixed factors or in conjunction with them the labile factors including vitamins would be supposed to act.

The difference in the kind or amount of the fixed factors is also exemplified in the different needs of the young and the older pigeons. For it was seen that very young pigeons cannot grow or remain healthy on whole cereals, although older pigeons can.

While agreeing in general with the observations of McCarrison (1919) concerning the changes in the organs, the writer is disposed to attribute greater importance to the destruction of the pancreas than has hitherto been recognised. In the writer's experiments even on whole cereals, maize, or rice, the diminution in the weight of the pancreas is marked, while on polished rice it may be reduced readily to a sixth of the normal and may be found in a semi-fluid condition. Side by side with this dissolution of the pancreas is an accumulation of material, presumably carbohydrate, in the liver. This increase of weight of the liver is remarkable inasmuch as the organ is also softening and becoming diseased, so that it would appear that in the liver two changes are occurring, a disintegration of true liver substance and an accumulation of stored material. It will be important to decide if this is a storage of glycogen although it seems almost certain that it is.

\section{Conclusions to Section II.}

1. That a diet exclusively of cereals and especially of polished or overmilled cereals leads to a metabolic disturbance which affects in varying degree all the tissues of the body, and that the so-called polyneuritic symptoms are but one of the manifestations of the disease, and by no means the most common, even in birds.

2. That the interests of the study of malnutrition in man is best served by drawing a comparison not between the man as a whole and the animal as a whole, but between the condition of one or more systems in the one and in the other. The question should therefore no longer be, Is the rice disease in fowls and pigeons the same as in man? which might possibly have scientific but 
certainly no clear medical meaning, but rather is one or more system in man in the analogous condition to the corresponding system in the experimental animal. Thus it may be found, as in the writer's experiments, that in one breed of pigeon there is an involvement of certain systems and in another breed of pigeon other systems are more obviously implicated. Each case properly selected might be used to study the changes themselves with a view to throwing light on the corresponding condition in man.

3. That in the writer's experiments the commonest type of affection produced in pigeons on a diet of polished rice resembled more the prevalent type of Beriberi in Japan, than the exceptional case with marked nerve lesions, and that it is likely a study of the non-neuritic type of the disease in birds will help much towards an understanding of the analogous condition in man.

\section{Section III. A Consideration of various Factors which protect Pigeons against the harmful efFect's of an exclusively Cereal Diet, and especially of Polished Rice.}

\section{Enumeration of the Protective and Harmful Factors.}

As suggested in Section II of this communication, we may conveniently call those factors which reside in the tissues of the animals, fixed factors, and those which may be extracted from the tissues or which obviously act from without, mobile factors, conceptions somewhat analogous to those employed in describing the phenomena of enzyme action. The following factors, at least, must be taken into account in order to solve the problem of malnutrition in birds resulting from diets of cereals, especially when overmilled or polished.

Fixed factors:

Factors acting beneficially.

(a) Depending on the breed of pigeon.

(b) Depending on the history of the pigeon. (Habits, environment etc.)

Mobile factors:

(a) Known chemical constituents of food, such as protein, mineral matter, etc.

(b) Certain non-protein nitrogenous substances, not definitely known.

(c) The vitamin B complex.

(d) Vitamin A.

(e) Radiated material in food (vitamin $\mathrm{D}$ ?).

$(f)$ Heat (in moderate degree).

Factors acting harmfully:

Excessive energy exchange in the tissues.

Inadequate aeration of the tissues.

Inadequate excretion.

Excessive humidity in the atmosphere. 
And it is probable that the same factors must be taken into account in order to solve the problem of analogous malnutrition in man.

The object of the present communication is to emphasise the reality of these various factors in connection with the problem in hand.

\section{Fixed Factors protecting against Deficiency Disease.}

Considering firstly the fixed factors, we may recall evidence of deficiency disease in general, which shows the very different resistance of different species of animals, and leads to the conclusion that they differ in respect of reserves of protective substance. One recalls for example the finding that on a diet exclusively of wheat, hens may be healthy, rats and pigs develop "polyneuritis," and guinea-pigs scurvy: see Berg (1927). Maize according to Holst and Fröhlich (1907) is harmless to pigeons, hens and rats, while on this food rabbits develop "polyneuritis," and guinea-pigs scurvy, facts confirmed by Schaumann (1910), while Weiser (1912) finds guinea pigs cannot live on maize only. The writer's experiments, described in Section II of this communication, show that older pigeons can live on cereals, but not the very young, and such findings call to mind similar observations by Chick (1926), Lopez Lomba (1921), Drummond (1916) and Drummond and Coward (1920), Plimmer (1927) and Boas (1927), which may be interpreted in the light of the idea of fixed protective factor. Experiments also on the transmission of such protective factors to the offspring, as for example those of Sieffert (1922), McCollum and Davis (1915), and Hopkins (1923) point in the same direction.

The very different resistance of pigeons of different breeds, especially of wild as compared to tame birds, which have been pointed out by the writer, and agree with findings by McCarrison (1919) in many respects, add to the evidence.

Nor must the evidence of clinical experience be forgotten, pointing to individual and racial differences in respect of diathesis. Such differences impressed themselves upon the writer when in Japan, especially in regard to country bred and town bred people, between those leading an active and a passive life, although living on a very similar diet. The existence of such factors will therefore probably be generally admitted.

That they are fixed factors is shown firstly by their being inherited, secondly by the fact that the tissues of an animal in the condition of deficiency disease atrophy rapidly, and it is reasonable to attribute this breakdown to a necessity of liberating fixed factors and transforming them into labile factors or vitamins, thirdly the origin of vitamins from a precursor or fixed factor is suggested by the production of these substances during germination and growth, as in the experiments of Williams and Seidel (1916), Harden and Zilva (1921), Funk and Dubin (1921), Fulmer and Nelson (1923), Funk and Freedman (1923), Eddy and Kerr (1924), and others. Finally there is the evidence that the administration of one vitamin helps in the production of or in sparing another. Some evidence of this kind is given in the present communication. 
Mobile factors protecting against deficiency diseases.

The known food factors. McCollum (1925) points out that natural rice lacks at least four, and polished five factors, which are necessary for healthy life of pigeons. These include known factors such as protein, fat, and mineral matter. It would be idle therefore to consider the harmful effects of polished rice as though these known factors were already supplied, and as if the only deficiency was in respect of accessory factors. Yet the Far Eastern Association of Tropical Medicine (1925), though quite rightly emphasising the importance of vitamin B in preventing Beriberi disease, did not take the opportunity of emphasising the many deficiencies of even whole rice as a diet. Such emphasis is badly needed in Japan, where the tendency has been to forget the early work of Takaki (1887).

\section{Nitrogenous Substances known and unknown, in possible relation to the Vitamin $B$ Complex.}

The writer could never agree with the statement so frequently made in text books upon the subject of nutrition, that until the recognition of the existence of vitamins or accessory factors physiologists taught that the only essential food factors were fat, carbohydrate, protein, and mineral matter. Justus Liebig (1851) certainly taught nothing of the kind. On the contrary he stated that if meat is extracted with hot water the residue is instinctively rejected even by dogs, and he lays great stress on the importance of extractives. Moreover the importance of lipoids and their derivatives, of creatine and creatinine, of purins and allied nitrogenous substances was very well recognised by surely most physiologists. The stimulus given to nutritional research by the renewed faith in the possibility of isolating vitamins is sufficiently obvious in the history of the subject in the last fifteen years, but the facts should not be allowed to get so far out of perspective as to undo the good done in the past.

There is indeed a certain amount of evidence that there is an intimate relation between the vitamins and certain basic substances, and polyneuritis so called has been in many cases warded off by administration of nitrogenous preparations.

The crystalline preparations, which Funk (1911) considered at first to be pure vitamin, were nitrogenous substances, curing the nervous symptoms of pigeons in very minute doses. The preparations turned out to be mixtures, and the general idea now is that the cures were effected by the trace of vitamin in the mixture of nitrogenous substances themselves inert.

But it is possible that the vitamins, even if not compounds of nitrogen, may yet require the co-operation of soluble nitrogenous substances for their action.

The probable co-operation of nitrogenous substances is seen also in the curative action of yeast. A very little fresh yeast may cure or prevent polyneuritic symptoms and supply vitamin necessary for growth, but in order to even maintain body weight on yeast which has been heated to $100^{\circ} \mathrm{C}$., a 
considerable quantity is required, the benefit being proportional to the amount used. A gram per day of heated yeast is required to maintain body weight in pigeons to which $30 \mathrm{grm}$. of polished rice is being given, and even then, as may be seen from Fig. 7, the body weight is maintained with difficulty. Such a large requirement of material seems to denote a chemical process of the more

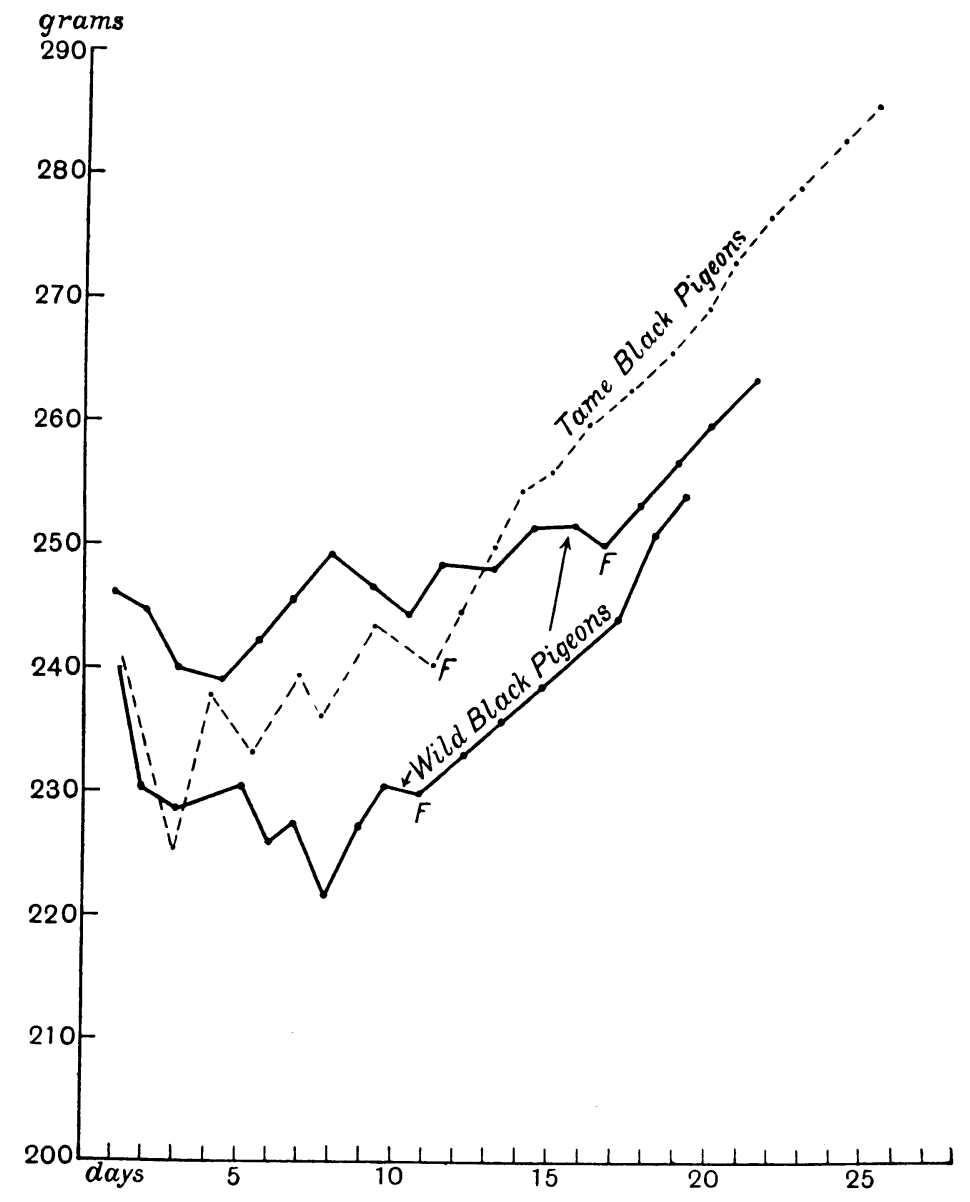

Fig. 7. Showing that body weight is maintained on polished rice with an addition of yeast dried at $100^{\circ} \mathrm{C}$., but weight increase is very slow. On addition of fresh yeast weight increase is rapid. With the heated dried yeast the curves show fluctuations, but with fresh yeast the curves are smooth.

Fresh yeast was given at the point marked $F$.

familiar type and not a catalytic process such as one is inclined to consider vitamin action to be. The real vitamin-like action is shown on the addition of the fresh yeast, represented on the diagram, Fig. 7, by the letter $F$. The diagram also shows that there are many fluctuations in the body weight curve, when yeast dried at $100^{\circ} \mathrm{C}$. is the sole addition made to the polished rice, and similar fluctuations are seen in the body weight curves of pigeons fed on a diet 
of cereals only. The irregularities are not seen in curves representing growth on diets containing beans, or cod liver oil, or fresh yeast (see Fig. 7 and also Fig. 6 in Section II of this communication). The fluctuations may probably be attributed to unequal retention of body fluids. It may of course be that the body weight is maintained by a special thermostable substance which the German investigators refer to as "Erhaltungsstoff" as distinct from "Wachstumsstoff" (see R. Berg (1927), p. 535). This would give us at least three vitamins or accessory factors in yeast, the antineuritic, the growth factor, and the Erhaltungsstoff (which we might translate as "resistance factor").

It seems however to the writer that every effort should be made to determine the part played by various nitrogenous substances in yeast and other extracts before concluding that so many vitamins are necessary to explain the phenomena.

There is the possibility also that there is a deficiency not merely of total nitrogen, but that certain special nitrogenous substances are needed to cooperate with the vitamins. Durham (1904) observed from the beginning of the rice disease a negative nitrogen balance. Schaumann (1910 and 1914) likewise observed a progressive negative nitrogen, phosphorus, and calcium balance. Lavialle (1924) found a benefit in adding egg white, though not against the neuritic symptoms. Edie, Evans, Moore, Simpson and Webster (1912) found benefit with casein, though attributing the benefit to vitamin. Funk (1913) obtained some protective action with certain bases, and the writer has observed that barbituric acid can protect pigeons and prolong the onset of the symptoms of rice disease. It may be that the action of such bodies, especially such as are related to purin or urea, may be merely indirect in an effect upon the kidneys, but the matter deserves attention.

The fact therefore that many, for example Manson (1901), Bréaudat (1911), Aron and Hogson (1911), Schaumann (1914), Chick (1917) and Plimmer (1927), observe Beriberi in man or the analogous condition in animals to occur in spite of abundant protein, need not be viewed as contradicting the other results, but rather that the vitamin is one factor and the nitrogenous substances represent another factor in protecting the organism from the harmful effects of a cereal diet especially when the cereal is rice or maize.

\section{Vitamin $A$ aiding or sparing Vitamin $B$.}

In attempting to replace the factors missing in the cereal diet, especially with maize and rice, experiments were carried out upon the effect of the addition of cod liver oil. No special benefit was observed in the case of the whole cereals, but with polished rice the quite remarkable result was observed, namely that after about ten days' treatment with cod liver oil the birds were in a position subsequently to resist a diet of polished rice for a very much longer time than was possible with birds who had received no oil. Fig. 8 shows the protective effect referred to. It will be seen that the birds which had received 
cod liver oil lived over thirty days while the control birds which had received no oil died in half that time. It is interesting to note that the birds which had received the oil, and were thus able to live much longer, ultimately died suddenly with marked disturbance of the nervous system, turning backward somersaults immediately before death. It happened that the two controls

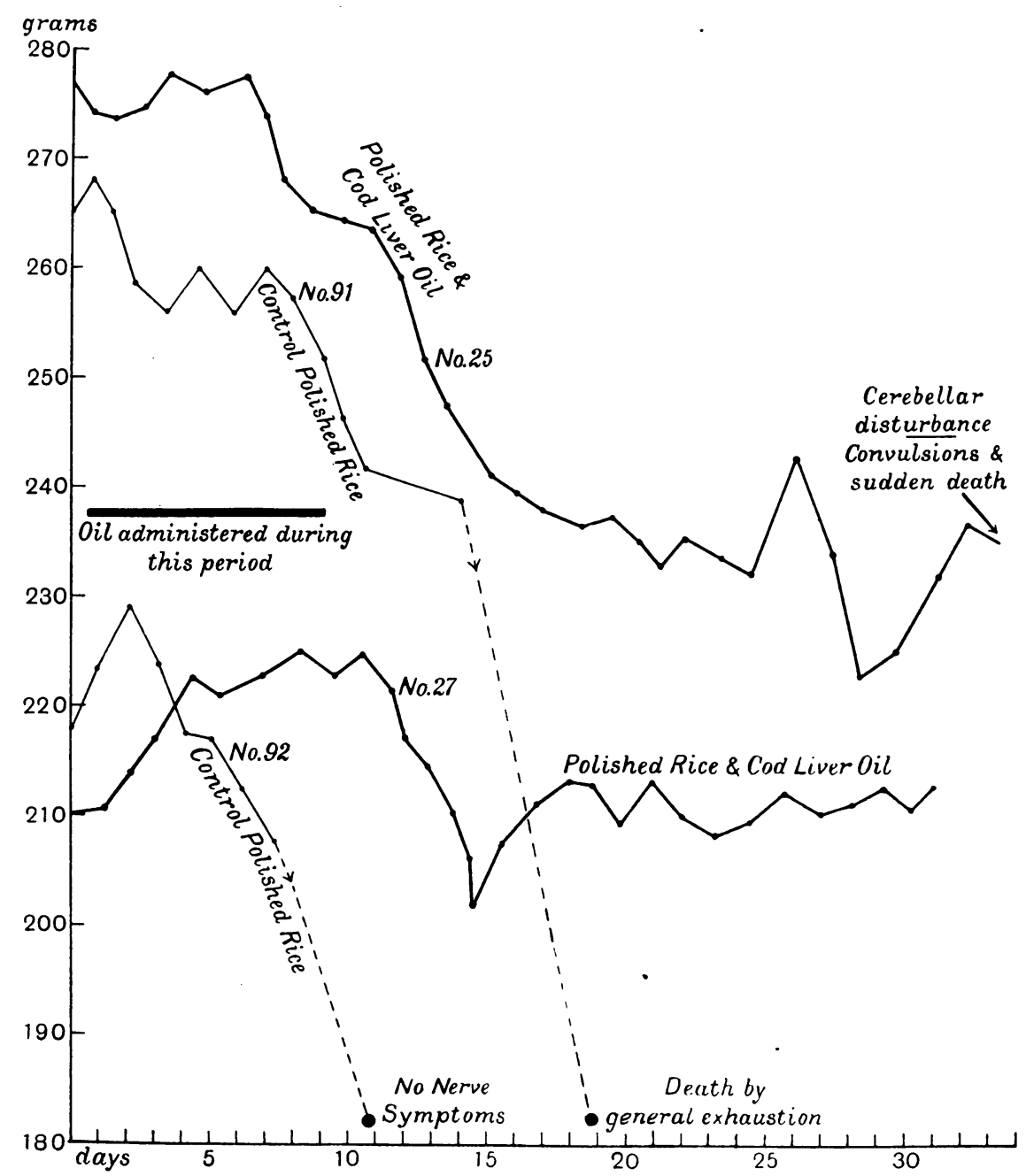

Fig. 8. Showing the action of cod liver oil in protecting pigeons from the harmful effects of a polishea rice diet. The birds live longer, but death when it occurs appears more suddenly.

died without showing neuritic symptoms, other controls survived to twenty-one or twenty-two days and showed in these cases the characteristic neuritic symptoms, but none of the birds ever lived to thirty-five days on a diet of polished rice other than those which had had cod liver oil for the first ten days, or had been protected in another way to be described later. The experiments 
point therefore to the ability of vitamin A, administered early, to protect pigeons against the subsequent action of the polished rice diet. The protection does not last long, nor does it counteract the convulsions with which death is ushered in, nor is it in any sense a cure for the rice disease, but the fact that some protection is so afforded indicates a relation between vitamin $A$ and $B$, in that their action is to a certain extent complementary, or co-operative. The experiments recall the observations of Hopkins (1923) that in the absence of vitamin B, vitamin A may exert an actually harmful influence, or of Sieffert (1922) who showed the weakness of progeny born of parents fed with A but insufficient $\mathrm{B}$, in so far at any rate as all these experiments indicate some cooperation in the action of the vitamins.

\section{The possible Protective Action of Ultraviolet Light.}

In common with others, the writer has observed that radiation of pigeons for short or long periods was without any benefit either as a prophylactic or

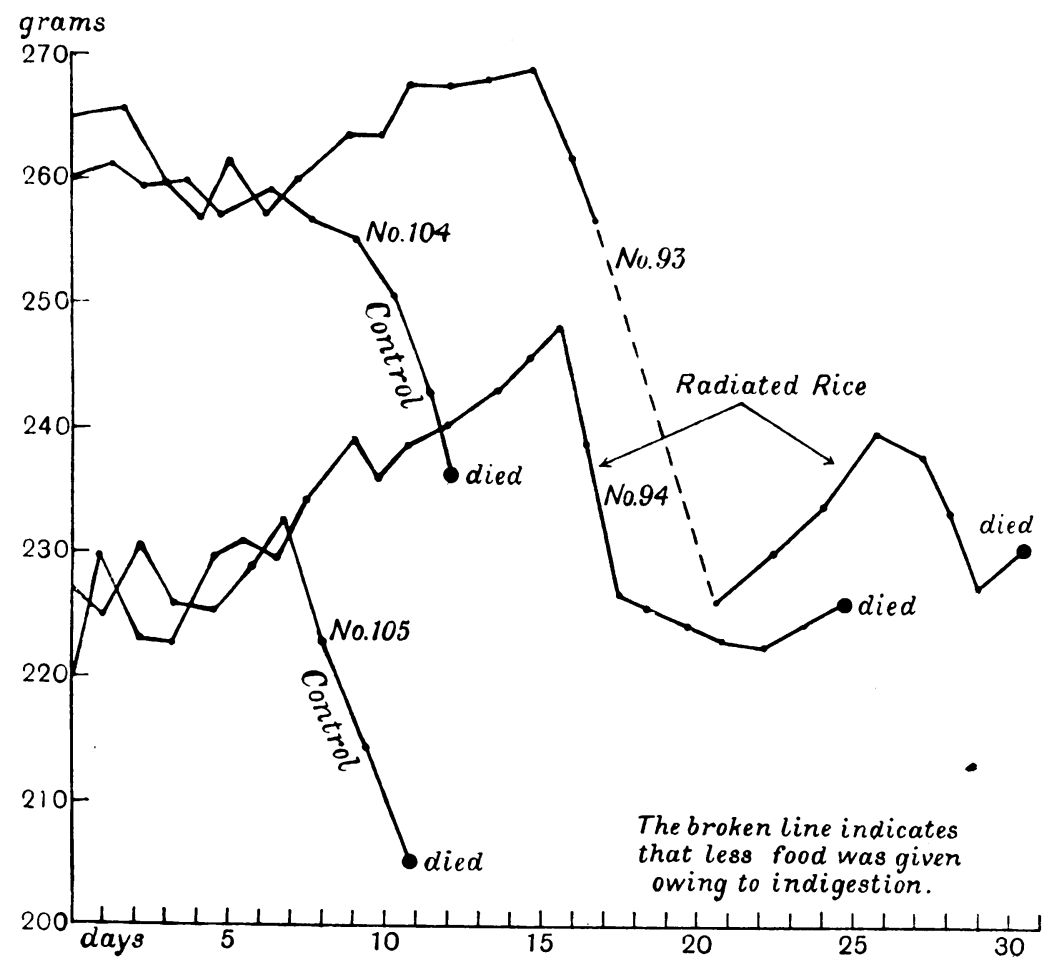

Fig. 9. Showing the beneficial effects of radiation of polished rice in prolonging the life of birds fed on a diet exclusively of polished rice.

curative measure, and likewise the radiation of natural foods did not help but rather rendered them indigestible, and in the case of natural rice and yeast appeared to destroy some of the vitamin. It was thought however, that possibly 
white rice which had so to speak never been properly radiated by the sun, might benefit by the treatment, and curiously enough the results of the experiments seemed to indicate that there may be some truth in this idea (see Fig. 9). The number of experiments so far carried out does not suffice to make a definite statement in the matter but they seem at least worth recording, inasmuch as if the facts should turn out to be as surmised, the practical application of the results may be of benefit.

\section{The Effect of Heat.}

The fact that the body temperature of rice-eating people, such as the Japanese and Chinese, is about a degree lower than that of most other races, is surely highly suggestive, as is also the fact observed by certain Japanese workers such as Koroidzume (1925) and by Earle (1926) ${ }^{1}$ in Hong Kong, that the basal metabolism of Japanese and Chinese people is definitely lower than that of the European living in the East.

It seems to the writer that this lowered basal metabolism may indicate either a reaction on the part of the body to the harmful effect of a diet of too high calorific value, or an imperfect development of the heat controlling mechanism as a result of insufficient nourishment of the nervous system. On either of these views a rise of general body temperature above a certain point would be expected to exert a harmful action, as increasing the metabolic rate in an organism unadapted to the higher level of metabolism. On the other hand mere superficial warming of the body would not be expected to do harm and might do much good, by encouraging the functioning of the skin, reflexly improving tone, and relieving congestion of internal organs by encouraging the flow of blood to the surface of the body.

We might therefore anticipate two effects of heat, a beneficial effect of a short application, or moderate degree of heat, and a harmful effect of a prolonged action or intense degree of heat.

The Japanese people have made this discovery empirically and soak their bodies almost each day in very hot water for about thirty minutes, and for the rest of the day they go lightly clothed. This treatment may not be so essential in dry climates but in the damp climate of Japan it seems essential for such as live on a rice diet.

In the case of animals, one has frequent evidence of the beneficial effect of warmth in counteracting the effects of an inadequate diet, and conversely the increased susceptibility of such animals to cold. Sometimes special symptoms may be treated by warmth as for example the convulsions of rice-fed birds, which Kinnersley and Peters (1925) found could be calmed by warmth.

The writer has also observed that in the warm weather in Egypt pigeons do not so readily become exhausted by a diet of polished rice.

On the other hand, that a prolonged application of heat may be harmful seems evidenced by the fact that in Japan it is in the months of most intense

1 Private communication. 
heat, namely July, August and September, that Beriberi breaks out. Humidity undoubtedly plays an important part in causing the onset of symptoms, but there seems much evidence pointing to the conclusion that the actual excessive application of heat is harmful, more particularly in rice-eating peoples than in others.

\section{The Importance of Excretion.}

That unhygienic conditions may hasten the outbreak of Beriberi and analogous conditions is well known, and taken into consideration with the practices in Japan referred to above, as well as with general clinical experience, lead us to the conclusion that in the case of malnutrition, apart from the possible effect of bacterial infection, which of course may be superadded, there is evidence of an accumulation of toxic products not formed when nutrition is normal. This takes us it is true partly back to the view of Eijkmann (1897) but Abderhalden (1918), McCarrison (1919, 1924), Fraser and Stanton (1924), Berg (1927) and others have all been profoundly impressed by the toxic appearance of the rice-fed animals. The writer feels convinced that these workers are right in their view that something toxic is produced, and for the following reasons: the organs are undergoing rapid autolysis while excretion is becoming impaired, through destruction of the kidney, congestion of the lungs, and impaired action of the skin, which is evidenced in the case of birds by the condition of the feathers, and the appearance of atrophic patches. Moreover the writer has found that when the bird is in a state of collapse it may be saved by washing out the crop with warm water. The material removed by this washing out was not found to be contaminated by micro-organisms, but was strongly acid.

It was observed also that the condition of birds fed on polished rice could on occasions be much improved by withholding the food, or by diminishing the amount given. On the other hand death could be hastened by giving cane sugar or glucose by the mouth.

It is clear therefore that the birds die not merely through absence of something they want, but through the presence of something they do not want. Death is not merely starvation as Drummond (1927) suggests.

It is of course not necessary to suppose a poisonous substance of a very special kind, it may be that there is merely an excessive accumulation of normal products of metabolism, which can no longer be removed or destroyed, and it would still remain as a question whether such hypothetical products arose by autolysis of the tissues of the animal, or by hydrolysis of the rice.

\section{Conclusions to Section III.}

1. That various chemical factors, some in the tissues of the animal (fixed factors), some in the food or which may be formed in the animal (mobile factors), as well as physical and physiological factors, must be taken into account in explaining the disease induced in an animal by an entirely cereal diet and especially a diet of polished rice. 
2. That there is much evidence of the accumulation of toxic material in birds suffering from "rice disease" though it is not certain whether the toxic material comes from the tissues of the bird or from the rice.

3. That as a working hypothesis it may be held that the trouble from which animals suffer when fed on cereals overmilled and especially polished rice is an acute form of the condition in which all animals are found which subsist on food with a low nitrogen intake and a high calorific value, namely that the tissues are called upon to do excessive metabolic work, while at the same time they are not supplied with the nitrogenous repairing material requisite for tissue repair.

4. That the actions of vitamin B complex may be attributed to two factors:

(a) A factor which catalyses enzyme actions in the tissues, especially of the oxidative type, and is therefore concerned in the regulation of combustion, and hence energy production in the tissues, no matter whether of carbohydrate, fat, or protein.

The greater the combustion the greater will be the call for the co-operation of this factor.

(b) A factor which maintains the integrity or tone of the tissues.

In the absence of this factor the cell structures become autolysed, permeable to fluids, and finally disintegrate.

5. On these views the known nutritional factors are compared to spare parts of the machinery, and the accessory factors to governors or regulators of the mechanism. Destruction of either must lead to deficiency disease.

6. The various signs and symptoms of polished rice disease may be explained in terms of the factors and accessory factors postulated above. Thus in the absence of the first factor of the vitamin B complex, energy cannot be produced without an abnormal destruction of the machinery, i.e. the tissues of the body.

The disintegration of the tissues is resisted by the second factor, which maintains tone, but when this gives out there is a rapidly increasing permeability of the tissues, with consequent softening of the organs, inflammatory and catarrhal conditions, oedema, congestion, haemorrhage, diarrhoea, increased liability to infection, and so forth.

The order in which the various tissues would become involved would be proportional to their vascularity, to the amount of work thrown upon them, the pressure to which they were subjected, and inversely to their natural resistance and the extent to which they were mechanically supported. The order would therefore probably be, endothelial or epithelial, glandular and plain muscle, skeletal, and finally nervous. The neuritic symptoms would be expected to appear late, and would be the expression of a congestion of lymph or even haemorrhage into the tissue causing an irritation of the nerve cells. It would thus not be necessary to postulate a special anti-neuritic substance. 
7. The fact that the heart, though highly vascular, and called upon for continuous work, should resist better than other organs to the harmful effects of malnutrition, argues for it a special endowment of the fixed factors postulated in this communication, and suggests a subject of highly interesting study.

The views here set forth, though arrived at quite independently have clearly something in common with those expressed by Ragnar Berg, Abderhalden and others of the German school, who postulate an "Atmungsstoff" or co-catalase, and an "Erhaltungsstoff" which helps to maintain body weight but not growth.

My best thanks are due to Sir Frederick Gowland Hopkins for valuable help and criticism.

\section{REFERENCES.}

Abderhalden, E. (1922). Arch. gesamt. Physiol. 197, 9.

Abderhalden, E. and Ewald, G. (1918). Zeitschr. exp. Med. 5, 1. Zentralbl.f. Biochem.u. Biophys. 19, 551.

Aron, H. and Hogson (1911). Biochem. Zeitschr. 32, 189. Chem. Centralbl. 68, 158.

Berg, R. (1927). Die Vitamine. Leipzig: S. Hirzel. 2nd ed. Pp. 102 et seq.

BoAs, M. A. (1927). Biochem. Journ. 21, 712.

Brfaudat, L. (1911). Journ. pharm. et chim. (2), 4, 447. Zentralbl. f. Biochem. 12, 577.

CHICK, H. (1926). Biochem. Journ. 20, 119.

CHICK, H. and Roscoe, H. M. (1927). Ibid. 21, 698.

Chick, H. and Hume, E. M. (1917). Journ. Roy. Army Med. Corps, Aug. and (1917) Proc.

Roy. Soc. B. 90, 60.

Dickenson, D. Q. M. (1915). Trop. Dis. Bull. 8, 146.

Drummond, J. C. (1916). Biochem. Journ. 10, 77.

Drummond, J. C. and Coward, K. H. (1920). Ibid. 14, 734; (1921) Ibid. 15, 530.

Drummond, J. C. and Kon, S. K. (1927). Ibid. 21, 632.

DURHAM, H. E. (1904). Brit. Med.Journ. i, 480.

Dutoher, R. A. (1919). Journ. Biol. Chem. 39, 63 and (1920) Proc. Nat. Acad. Sci. 6, 10.

Eddy, H., KerR, R. W. and Williams, R. R. (1924). Proc. Soc. Exp. Biol. and Med. 21, 307.

Edie, E. S., Evans, E. H., Moore, B., Stmpson, G. C. E. and Webster, A. (1912). Biochem. Journ. 6, 234.

Eijkmann, C. (1897). Virchows Arch. 148, 523; (1906) Arch. f. Hyg. 58, 150.

Far Eastern Association of Tropical Medicine Report (1925).

Fraser, H. and Stanton, A. T. (1924). Collected Papers on Beri Beri. London: J. Bale.

Fulmer, E. I., Nelson, V. E. and White, A. (1923). Journ. Biol. Chem. 57, 397.

Funk, C. (1911). Journ. Physiol. 43, 395; (1912) Ibid. 45, 489; (1913) Ibid. 46, 173.

- (1913). Die Vitamine. Munich. 3rd ed. 1927.

(1914). Zeitschr. f. physiol. Chem. 89, 378.

(1922). The Vitamines. Translated by Dubin. Baltimore: Williams and Wilkins.

Funk, C. and Dubin, H. E. (1921). Journ. Biol. Chem. 48, 437.

Funk, C. and Freedman, L. L. (1923). Proc. Soc. Exp. Biol. and Med. 20, 311. (1921). Journ. Biol. Chem. 48, 437.

HARDEN, A. and Zituva, S. S. (1921). Biochem. Journ. 15, 438.

Holst, A. and FröHLICH, T. (1907). Journ. Hyg. 7, 634; (1911) Trans. Soc. Trop. Med. and Hyg. 5, 76.

— (1912). Zeitschr.f. Hyg. 72, 1. 
Hopkins, F. G. (1912). Journ. Physiol. 44, 425; (1923) Brit. Med. Journ. ii, 691.

Hopkins, F. G. and others (1923). Proc. Roy. Soc. Med. 13, 1.

Kinnersley, H. and Peters, R. (1925). Biochem. J. 19, 820.

Koroidzume, L. (1925). See Far Eastern Assoc. Trop. Med. Report.

Lavialle, P. (1924). Bull. Sci. pharmacol. 31, 376.

Liebig, J. (1851). Chemische Briefe. Heidelberg: C. F. Winter. pp. 503-547.

LOPEZ LoMBa (1921). Compt. rend. Acad. Sci. 172, 1682.

Lovelace, C. (1912). Journ. Amer. Med. Assoc. 58, 2134.

Manson, P. (1901). Lancet, ii, 1391.

MoCarrison, R. (1919). Ind. Journ. Med. Res. 6, 275 and 7, 167; (1920) Brit. Med. Journ. i, 822; (1923) Ibid. ii, 172; (1924) Ibid. i, 414.

- (1921). Studies in Deficiency Diseases. London.

McCollum, E. and Davis, M. (1915). Journ. Biol. Chem. 21, 615.

McCollum, E. and Simmonds, N. (1925). The Newer Nutrition. 3rd ed. New York: Macmillan.

Plimmer, R. H. A., Rosedale, J. L. and Raymond, W. H. (1927). Biochem. Journ. 21, 913.

Schaumann, H. (1910). Arch. Schiffs- u. Tropen-Hyg. 14, Beiheft 9.

- (1914). Ibid. 18, Beiheft 6.

Schaumann, H. and Abderhalden, E. (1918). Arch. ges. Physiol. 172, 1.

Sieffert, L. (1922). Schweiz. Apoth. Ztg. 60, 301, 313, 329.

Smith, F. and Hastings (1913). Journ. Roy. Army Med. Corps, $20,202$.

StePp, W. and György, P. (1927). Avitaminosen. Berlin: J. Springer.

TAKAKI, K. (1887). Lancet, ii, 86.

TASAwa, R. (1914). Zeitschr.f. exper. Pathol. 17, 27.

WeISER, S. (1912). Biochem. Zeitschr. 44, 279.

Williams, R. R. and Seiden, A. (1916). Journ. Biol. Chem. 26, 431.

Wirson, J. W. (1922). Journ. Biol. Chem. 51, 455.

(MS. received for publication 2. XII. 1927.-Ed.) 